\title{
Caminhos de uma historiadora para transformar o mundo: entrevista com Carolinne Mendes
}

Entrevista por Gabriele Maria Oliveira, Pedro José de Carvalho Neto e Yan Fernando Pereira Catuaba

Transcrição por Beatriz Gasques Favilla, Gabriele Maria Oliveira e Yan Fernando Pereira Catuaba

Revisão por Beatriz Gasques Favilla, Gabriel Yukio Shinoda Oliveira, Guilherme Oliveira Souza, Leticia Oliver Fernandes, Marina de Almeida Spinola, Matheus de Paula Silva e Pedro José de Carvalho Neto

DOI: 10.11606/issn.2318-8855.v9i2p264-296 


\section{entrevista|}

Caminhos de uma historiadora para transformar o mundo

Carolinne Mendes nunca sonhou em cursar História, nem em ser professora. Dividida entre o interesse pelo cinema e as perspectivas reais do mercado de trabalho, ingressou no curso em 2005 sem saber muito bem no que ia dar. Foi já na universidade que se apaixonou pela área e se descobriu uma historiadora. No entanto, não deixou a paixão antiga de lado: em suas pesquisas, articula história, cinema e a urgência de pensar sobre (e transformar) a sociedade brasileira.

A entrevista é tão diversa quanto pede a sua trajetória. Carolinne falou sobre as múltiplas experiências profissionais, da pesquisa à escrita de livros didáticos, do trabalho CLT ao freelance, das salas do Ensino Fundamental às da EJA - e sobre como tudo isso se encaixa. Destacando a importância de ter conhecido na prática tantas áreas de trabalho, convida os jovens estudantes a se permitirem, também, experimentar para descobrir o próprio caminho.

Boa leitura a todas e todos!

Revista Epígrafe: Por que você quis fazer História? De onde veio isso? Você já tinha um interesse antes por História?

Carolinne Mendes: Na verdade, não foi nada escolhido e planejado de uma forma muito certa, assim, de um desejo de ser historiadora ou professora de História, nada disso. Porque, quando eu terminei o ensino médio, eu queria estudar cinema e eu era uma aluna muito nerd que fazia o ensino médio numa escola particular aqui de Osasco. Quando eu estava no final do ensino médio, eu consegui uma bolsa para fazer cursinho intensivo e todo mundo depositava muita fé que eu ia passar. E eu prestei vestibular para audiovisual, só prestei USP [Universidade de São Paulo], e não passei nem na primeira fase, e isso me deixou muito para baixo; quando foi no ano 


\section{entrevista}

Carolinne Mendes

seguinte, eu continuei fazendo cursinho, mas aí foi chegando mais ou menos no meio do ano, eu falei "eu não vou passar em audiovisual, não vou passar", e aí eu decidi prestar História, porque, durante o ano, eu fui curtindo muito estudar História, comecei a ler algumas coisas, não só de livro didático, mas de trabalhos historiográficos mesmo, e eu falei "eu vou prestar História, porque eu gosto de estudar História", sem ter a menor noção de com que eu ia trabalhar, no que isso ia dar. E aí eu prestei História para a USP, prestei Cinema para a UFscar [Universidade Federal de São Carlos], prestei Rádio e TV para a Unesp [Universidade de Estadual Paulista] e Midialogia na Unicamp [Universidade de Campinas]. Aí eu passei e eu acabei escolhendo ficar na USP por conveniência, por não ter que mudar de cidade... la ter um custo se eu fosse fazer, por exemplo, Cinema na UFscar, que eu até cheguei a fazer a matrícula, mas aí pensei “ia ter que mudar para lá, não ia conseguir emprego, como é que eu ia me manter lá?", então tinha todas essas dúvidas. E também comecei a ficar receosa com o mercado de Cinema, pensei “mas será que vou conseguir trampo nessa área?" e tal... "Acho que fazendo História talvez seja mais fácil de trabalhar como professora", embora fosse muito tímida e ainda não me imaginava muito. Pensava "se não tiver outro jeito, eu vou ser professora, algum trabalho eu vou ter" [risos]. E aí eu resolvi ficar na História mesmo.

Revista Epígrafe: E depois que você entrou, como foi sua experiência na graduação? Teve algum professor que te marcou? Teve algo que te marcou na sua trajetória?

Carolinne Mendes: Então, assim que eu entrei, eu me apaixonei muito pelo curso; foi meio por acaso, mas caí no que eu queria mesmo. Gostava muito das disciplinas que eu fazia e tal, embora sempre tenha alguma coisa que a gente não gosta, algum professor que a gente não gosta tanto, mas senti que eu estava no caminho certo. 


\section{entrevista}

Caminhos de uma historiadora para transformar o mundo Uma possibilidade que eu pensava era de tentar transferência para audiovisual se eu não curtisse, mas falei “não, o negócio é História mesmo". E aí, no primeiro ano de graduação, eu já comecei a pensar que eu queria seguir a carreira acadêmica, que, acabando a graduação, eu queria fazer um mestrado, queria fazer doutorado.

O que mais me chamou a atenção, desde o início, foi o estudo das relações raciais no Brasil, foi um processo, de entender melhor essa questão do racismo no Brasil e, até mesmo, de me reconhecer como negra, porque antes da graduação, eu não tinha essa noção, eu não me reconhecia enquanto pessoa negra ou enquanto pessoa que sofria racismo. E aí estudar o racismo no Brasil para mim passou tanto por questões pessoais quanto por poder interpretar melhor a realidade brasileira mesmo. Aí, já no início da graduação, uma professora que me marcou foi a Maria Helena P. T. Machado, eu lembro que eu fiz a disciplina de História do Cotidiano com ela, e tinha muito essa perspectiva do cotidiano das relações raciais no Brasil, no final já do século XIX, de pensar melhor como eram essas relações entre senhores e escravizados ou, no fim da abolição, como que as coisas aconteceram e tal. E aí eu já comecei a pensar também que queria fazer um mestrado que fosse mais ou menos nessa direção de estudar relações raciais no Brasil.

Depois, mais para o fim da graduação, eu conheci o professor Maurício [Cardoso], que foi meu orientador de mestrado e doutorado. E aí, na verdade, mais para o final da graduação, eu fui começando a fazer umas disciplinas optativas na ECA [Escola de Comunicação e Artes], as disciplinas de História do audiovisual, eu fui fazendo todas; e eu ainda tinha esse desejo de estudar Cinema, mas eu comecei a fazer uma IC [iniciação científica] de forma mais informal com a professora Maria Helena P. T. Machado, que era uma iniciação sobre as fotografias do Militão de Azevedo, principalmente os retratos de pessoas negras que fazem parte do acervo dele no Museu Paulista. E aí eu tinha iniciado essa IC, mas ainda tinha esse desejo de 


\section{entrevista}

Carolinne Mendes

estudar Cinema. Isso foi quando, no último ano, eu conheci o professor Maurício Cardoso, ele dava uma matéria optativa que era Cultura Visual e Ensino de História, aí eu comecei a fazer trabalho para ele sobre o negro no cinema brasileiro, gostava muito da disciplina dele, gostava muito dele como professor. Quando foi no final desse semestre que eu estava fazendo o curso dele, ele perguntou se eu não queria continuar essa pesquisa que eu estava fazendo para o trabalho em um mestrado. E aí eu falei assim “Nossa! Eu super quero! Acho que era o que eu sempre quis, mas eu estou fazendo essa I.C. com essa outra professora e eu queria muito já entrar no mestrado assim que eu terminasse a graduação..."; na época, eu fazia estágio e não queria ser efetivada nesse estágio, não via muita perspectiva de emprego, então, eu queria pelo menos já emendar logo o mestrado. E aí eu falei para ele, já estava terminando a graduação, "será que dá tempo ainda de eu fazer um projeto e já me inscrever para o mestrado contigo, com esse tema?", e ele falou "dá sim, vamos fazer". E aí eu conversei com essa professora, que eu estava desistindo daquela pesquisa e já prestei o mestrado com o professor Maurício.

Revista Epígrafe: E a gente queria, então, que você contasse um pouco mais sobre essas experiências de estágio. Como foi isso?

Carolinne Mendes: Bom, durante a graduação, eu fui passando por vários estágios. 0 primeiro estágio meu foi na Livraria da Vila, que eu entrei sem saber exatamente por que uma livraria contratava um estagiário de História, mas na época eu não estava escolhendo realmente, foi o primeiro trabalho que eu fui aprovada, então eu falei "vamos lá!". E era um trabalho que, basicamente, não tinha relação com o curso de História, então o estagiário trabalhava como um outro funcionário da livraria, principalmente nas sessões de encomendas, de atender esses clientes que queriam 


\section{entrevista}

Caminhos de uma historiadora para transformar o mundo fazer encomendas, ou na sessão de fazer pedidos para as editoras, verificar os materiais que chegavam das editoras e de ir em algumas feiras que a livraria fazia em alguns locais. Isso foi em 2006, gente, então minha memória às vezes até falha [risos]. E aí eu fiquei dois meses nesse estágio. Por causa dessas feiras que a gente tinha que trabalhar, acontecia que não tinha hora para acabar, e, na real, quando dava a hora de eu ir para aula - eu fazia aula à noite -, eu pegava e falava "olha, eu tenho que ir para a aula", e aí, por causa disso, depois desses dois meses eu fui mandada embora.

Aí eu continuei procurando outros estágios e fui trabalhar em um centro de memória que pertencia ao Clube Atlético Paulistano. Não sei se vocês conhecem, o Paulistano é um clube de elite de São Paulo que fica ali nos Jardins, no finalzinho da Rua Colômbia e início da Rua Augusta; é um clube que existe desde 1900, e eles têm um centro de memória onde eles têm troféus, medalhas que os atletas do clube já ganharam, e uma série de documentação, principalmente jornais, revistas, desde a época de fundação do clube até hoje. O Clube Atlético Paulistano era bastante importante no contexto de surgimento do futebol no Brasil; quando o futebol foi profissionalizado, o clube não se profissionalizou, mas nesse início do futebol, ele tinha ali uma relevância, então tem uma documentação sobre isso lá, e também uma documentação sobre a Revolução Constitucionalista de 1932, porque os sócios do clube participaram doando medalhas, na ajuda de primeiros socorros e tal, e aí tinha um material sobre isso lá também. Os estagiários desse centro de memória também, basicamente, faziam um trabalho que... que também não sei se essa é a melhor caracterização de estágio, porque a gente não tinha um supervisor direto, que rolasse algum tipo de aprendizado. Na verdade, a gente tinha que atender as pessoas que iam fazer as pesquisas, que geralmente não eram sócios, mas pesquisadores externos, então essas pessoas ligavam, mandavam e-mail querendo agendar as pesquisas, e aí a gente separava o material, atendia essas pessoas. E a gente escrevia 


\section{entrevista}

Carolinne Mendes

textos para a revista do próprio clube, então era muito no sentido de datas temáticas, por exemplo, o carnaval, aí a gente escrevia textos sobre os carnavais antigos do clube; no dia 9 de julho, por exemplo, sempre rolava um texto sobre a Revolução Constitucionalista. E, às vezes, o clube fazia umas exposições com esse material desse centro pró memória também, com essas medalhas ou com esses jornais antigos etc., e a gente participava dessas pesquisas para as exposições. Aí, lá no centro pró memória, eu fiz dois anos de estágio e, quando estava acabando, eu vi também que não ia rolar efetivação, não existia, assim, um cargo para se trabalhar como uma pessoa registrada lá no centro pró memória.

E aí eu comecei a procurar outros trabalhos já quando estava acabando o meu contrato, e eu consegui o meu primeiro trabalho CLT, que foi numa empresa chamada Arteducação Produções. Na época, essa empresa tinha sido contratada pela prefeitura, que terceirizou o trabalho de educação nas casas históricas de São Paulo; eram várias casas históricas, não lembro exatamente quantas, mas em torno de dez mais ou menos. A casa histórica que eu trabalhava era a Casa do Bandeirante, que fica ali no Butantã. E aí, em cada uma dessas casas históricas, que compõem uma coisa que se chama Museu da Cidade de São Paulo - que acho até que pouca gente conhece, porque não é um espaço único, mas um museu formado por várias dessas casas históricas; em cada uma, trabalhavam dois educadores: um formado em História e um formado em Artes. Então, a proposta do trabalho era arte e educação. E aí a prefeitura tinha terceirizado esse trabalho justamente porque, na época, essas casas iam começar a receber visitas regulares das escolas do Estado, que na época tinha um programa que chamava "Cultura é Currículo", que já previa que cada série do ensino fundamental iria fazer uma visita a algum espaço cultural, e aí essas casas foram inseridas nesse programa e os educadores, contratados para atender a esse público. Então, a gente basicamente atendia a esses visitantes, não só essas escolas 


\section{entrevista}

Caminhos de uma historiadora para transformar o mundo que iam agendadas, mas também um público espontâneo. E, além da gente fazer a visita, a gente geralmente tinha uma proposta artística, de realizar algum tipo de desenho ou jogo, no final dessa visitação. E aí eu fiquei trabalhando na Casa do Bandeirante por um ano e meio mais ou menos, eu acredito. O que me incomodava bastante no trabalho lá é que era de terça a domingo, então só folgava na segundafeira, trabalhava em feriados e tudo, e eu já estava bastante cansada por causa disso, e comecei a procurar outros trampos, e resolvi sair para ir fazer um outro estágio, mesmo que estivesse largando um trabalho CLT para ir para outro estágio, mas é porque eu ia ganhar a mesma coisa na época e trabalhando só de segunda a sexta.

Então fui trabalhar numa ONG [Organização não-governamental] que se chama Criança Segura, que estava contratando estagiários com o objetivo de trabalhar com arte e educação. Então, como eu estava trabalhando com isso na Casa do Bandeirante, eles gostaram do meu perfil e eu fui fazer estágio. Lá a gente entrava em contato com instituições de educação, fossem públicas ou privadas, e procurava levar o trabalho da ONG para essas instituições; a ONG trabalha com prevenção de acidentes com crianças, e eu trabalhava especificamente na área de acidentes de trânsito; a gente fazia formações com os educadores dessas instituições, com o objetivo de que eles replicassem essa formação com as crianças que eles atendiam.

Foi nesse momento - acho que tinha uns seis meses que eu estava fazendo estágio nessa ONG -, foi nesse momento que o professor Maurício Cardoso me chamou para fazer o mestrado com ele... Já estava, assim, mais ou menos em cima da hora, faltava, vamos supor, um mês para entregar projeto e me inscrever para as provas do mestrado. Aí eu pensei "bom, não vai dar"; eu larguei o estágio para me dedicar, fazer um projeto de pesquisa, para entrar no mestrado. 


\section{entrevista|}

Carolinne Mendes

Revista Epígrafe: E como foi a sua experiência na licenciatura? Você fez junto com a graduação ou você fez separado depois?

Carolinne Mendes: Sim, eu fiz a licenciatura junto e, como eu disse, ser professora seria minha última opção. Eu me considerava muito tímida; não achava que eu iria conseguir ser professora. Fiz a licenciatura naquelas, "vou ter esse diploma para me resguardar caso eu não consiga emprego em outra área". E realmente não me dedicava tanto às disciplinas, porque sempre procurava conciliar, pegar umas duas disciplinas na [Faculdade de] Educação, mais umas duas na História e acabava me concentrando mais nas disciplinas de História.

Durante o estágio obrigatório da licenciatura eu acho que me desanimei muito. Eu fiz em uma escola aqui perto da minha casa, que era uma escola onde eu tinha estudado no ensino fundamental - e até onde eu viria a trabalhar depois -, mas quando eu entrei na escola para fazer o estágio, a experiência era tão diferente de ter sido aluna que eu realmente fiquei muito assustada em ver como era difícil para o professor dar aula, o desrespeito e o desinteresse dos alunos... Eu falava "nossa, gente, que terror, vou fugir disso" [risos].

Revista Epígrafe: Queríamos que você falasse um pouco essa passagem da graduação para o mestrado e depois para o doutorado. Como foi para você essa escolha do tema? Como você vê esse caminho da sua pesquisa, o seu caminho acadêmico?

Carolinne Mendes: Então, como eu falei, desde o início da graduação, o tema que mais tinha me chamado a atenção era a questão das relações raciais no Brasil; e já imaginava fazer um mestrado sobre isso, já tinha um interesse por cinema que vinha antes mesmo de eu entrar para a história. E, aí, tinha começado, nessa matéria com o 


\section{entrevista}

Caminhos de uma historiadora para transformar o mundo

professor Maurício, a fazer um trabalho sobre o negro no cinema, e daí foi o tema que eu escolhi para entrar no mestrado.

Nessa época já, no final da graduação, eu comecei a me aproximar do Cinema Novo, acho que até pelas aulas optativas que eu estava fazendo no curso de Audiovisual na ECA, e comecei a gostar muito, a gostar de pensar essa relação entre esse movimento e o momento histórico em torno dos anos 1960, 1970. E aí eu pensei “Bom, para eu fazer um projeto de pesquisa, eu vou pegar esse período histórico que eu já estou me aproximando mais, já conheço um pouco desse cinema, acho que tem uma questão interessante aí, porque, nesse momento, os personagens negros começam a ganhar maior importância, começam a surgir protagonistas negros nesse cinema". E aí achei que era um tema interessante, então entrei para o mestrado com esse projeto de pesquisa que era "O negro no Cinema Novo"; depois de ter entrado, comecei a ver que seria melhor recortar esse tema e, conversando com o Maurício, eu decidi que realmente a melhor metodologia a ser usada seria a da análise fílmica. E falei "bom, para fazer uma pesquisa de mestrado com essa metodologia, eu preciso me concentrar em poucas obras"; então, assim, o início do meu mestrado foi muito no sentido de assistir, reassistir os filmes do Cinema Novo e decidir quais filmes eu estudaria. Aí eu optei por estudar um filme do Nelson Pereira dos Santos, que é o “Rio, Zona Norte", de 1957, e um filme do Cacá Diegues, que é "A Grande Cidade", de 1966. Então, eu vi que ali eu tinha dois protagonistas negros tratados em uma chave bastante diferente - o filme do Nelson Pereira dos Santos era praticamente um melodrama; o filme do Cacá Diegues já estava mais de acordo com o que se entendia ali sobre cinema moderno, um filme bastante fragmentado, com uma narrativa pouco contínua. E comecei a pensar em como essas duas formas narrativas poderiam me dizer sobre a importância desses personagens nos filmes e sobre a reflexão que os filmes faziam sobre a sociedade daquela época. 


\section{entrevista|}

Carolinne Mendes

Como durante o mestrado eu procurei mergulhar bastante nesse estudo sobre as relações raciais no Brasil dos anos 1950 e 1960, quando chegou no final do mestrado, eu já estava um pouco cansada desse tema. Aí comecei a pensar na importância das questões de gênero, que eu começava a ver que eu estava tratando tanto de racismo e que tinha outro tipo de discriminação, que eu via todo dia praticamente nas salas de aula, que era em relação à questão de gênero; e eu pensei “bom, eu acho que a minha próxima pesquisa teria que ser sobre isso". E aí eu já comecei a ter uma noção, nesse final de mestrado, que, quando eu fizesse doutorado, seria para pensar relações de gênero. Aí eu terminei o mestrado no meio de 2013, resolvi dar um tempo - até porque comecei depois a trabalhar em duas escolas -, e aí, em 2015, eu entrei no doutorado.

Já no final de 2014 eu comecei a pensar o projeto de doutorado, eu falei assim “Bom, vou continuar com Cinema Novo, porque é o objeto que eu já estou familiarizada, e vou pensar as personagens femininas". E aí eu tinha uma ambição de fazer um doutorado sanduíche, era uma coisa que eu queria muito fazer durante o doutorado, passar um tempo na França; eu já tinha começado a estudar francês desde o início do mestrado e eu pensei “bom, talvez não faça muito sentido ir estudar Cinema Novo na França", embora o próprio Maurício tenha feito isso [risos]. Mas eu pensava "não sei se vai dar certo, então eu vou fazer um projeto de doutorado que justifique melhor esse doutorado sanduíche", e pensei em comparar os filmes do Glauber Rocha com os filmes do [Jean-Luc] Godard, que já era um cineasta que eu conhecia bastante também; já gostava muito dos filmes da Nouvelle Vague e achava que lá, muito mais do que no Cinema Novo, tinha uma representação das transformações do papel da mulher na sociedade... E aí eu fiz esse projeto de doutorado, que eu me concentrei em quatro filmes de cada um, todos os filmes dos anos 60, quatro do Glauber, quatro do Godard e propus essa comparação. 


\section{entrevista}

Caminhos de uma historiadora para transformar o mundo

Quando eu entrei no doutorado, eu mandei o projeto para a FAPESP e ele foi muito criticado; a comparação foi tão criticada que eu não conseguia refazer o projeto mantendo a comparação; e aí eu falei "bom, acho que o jeito vai ser ficar com um dos dois cineastas", e acabei me decidindo por ficar com o Glauber, porque eu tenho um pouco de dificuldade, enquanto uma pesquisadora no Brasil, de me imaginar fazendo uma pesquisa que não seja sobre a sociedade brasileira. E aí eu refiz esse projeto e tal, e iniciei essa pesquisa de doutorado sobre as personagens femininas nos filmes do Glauber.

Quando foi na qualificação do doutorado - eu estava trabalhando com quatro filmes -, na qualificação, eu apresentei a análise de dois filmes, e os professores falaram que eu precisava avançar muito mais e não teria muito tempo para dar conta e sugeriram que eu ficasse com um filme só para o doutorado, que seria o Terra em Transe; e aí no início eu aceitei isso e comecei a mudar a pesquisa para fazer uma tese só sobre personagens femininas nesse filme.

Aí, quando foi no ano passado - eu terminei a minha tese em janeiro desse ano -, eu estava escrevendo já a tese só sobre Terra em Transe, eu falava "gente, só as personagens femininas desse filme não dão uma tese"; e eu estava extremamente desanimada com a minha pesquisa; eu já não acreditava mais que ia ter um trabalho minimamente bom, nem regular, e comecei a pensar que renderia melhor uma comparação entre vários filmes do Cinema Novo. Eu fui rever esses filmes do Cinema Novo pensando, inicialmente, em como eu poderia trazê-los só para comparar com Terra em Transe; e aí eu comecei a ver... "Mas, nossa, tem outros filmes em que as personagens femininas trazem questões tão mais importantes que não faz sentido eu fazer uma tese sobre Terra em Transe, mas citando outros filmes que me trariam questões mais significativas". E aí eu conversei com o Maurício, porque era uma loucura mudar o tema no último ano e aí eu falei que queria ampliar, não só para os 


\section{entrevista}

Carolinne Mendes

filmes do Glauber, mas para Cinema Novo, e ele achou que era uma boa, ele topou. E aí eu comecei a fazer análise desses outros filmes até decidir exatamente quais entrariam, e, no fim, eu fiz análise de treze filmes na tese. Então, teve essa mudança de última hora, mas que, na medida do possível, deu certo [risos].

Revista Epígrafe: Você começou falando que seu interesse era cinema; depois falou que seu interesse era relações raciais; depois falou que seu interesse mudou para relações de gênero; e, agora no finalzinho da sua fala, você terminou falando que você se via como uma historiadora no Brasil, da História do Brasil. Como você vê o encaixe de todas essas coisas? Como que isso tudo se encaixa na sua pesquisa?

Carolinne Mendes: Bom, eu acho que tem uma coisa muito certa, de pensar que as relações raciais são estruturantes para a gente pensar a realidade brasileira. Então, isso é uma coisa que esteve muito clara para mim desde o início da graduação e que eu, enfim, lendo trabalhos sobre a História do Brasil acho que nem sempre essa questão está tão clara, mas que, para mim, é bastante evidente que, se você vai fazer uma pesquisa sobre Brasil, as relações raciais têm que estar ali de alguma forma.

E, assim, eu acho que outra coisa que também ficou forte para mim, acho que desde a graduação, é pensar que meu interesse pela História, principalmente em relação ao fazer pesquisa, é pensar como que, de alguma forma, as nossas pesquisas também atuam sobre o mundo. Então, ainda que a gente saiba que os trabalhos acadêmicos fiquem muito restritos e não circulem pela sociedade e, muitas vezes, não role uma apropriação dessa pesquisa acadêmica, eu acho que, ainda assim, o trabalho acadêmico interfere, de alguma forma, na sociedade. Considerando isso, eu sinto uma relevância maior em tratar de questões de História do Brasil. 


\section{entrevista}

Caminhos de uma historiadora para transformar o mundo

Em relação a gênero, quando eu decidi ir para as relações de gênero, teve muito a ver com o que eu estava vivendo mesmo, com essa prática da sala de aula; eu comecei a ver que eu estava tão focada em pensar racismo que eu não olhava outras opressões - e, quando eu falo "olhava", eu digo tanto sobre meu objeto de pesquisa, que eram os filmes, quanto olhando na vida mesmo. E aí eu percebi que era algo relevante de se tratar, principalmente já que eu estava trabalhando no mestrado com os anos 1960, que é um momento onde você tem essa segunda onda do feminismo e tal.

Mas eu acho que minha ficha mesmo só foi cair no final desse doutorado, a partir do ano passado, principalmente, de entender um pouco as perspectivas interseccionais; de entender essa combinação de opressão entre raça e gênero, principalmente na minha pesquisa; porque, enfim, teriam outras coisas também, sexualidade, para pensar. Mas eu acho que, pensando no que eu já tinha estudado sobre raça, no que eu já estava estudando sobre gênero, demorou um pouco, na real, para eu chegar em autoras que fizessem eu compreender essa intersecção entre as opressões.

Revista Epígrafe: Voltando um pouco para o assunto da educação, a gente queria que você contasse um pouco mais como é que foi sua experiência como professora e como é que surgiu um interesse, nessa área, porque você disse que não era sua primeira opção de carreira... Como é que aconteceu isso?

Carolinne Mendes: Quando eu entrei no mestrado, eu consegui a bolsa FAPESP, e eu fiquei um tempo sem trabalhar. Depois, eu comecei a fazer alguns freelas no arquivo de jornalismo do SBT [Sistema Brasileiro de Televisão]. Mas, assim, todos os trabalhos que eu tinha tido até ali me pareciam muito instáveis e quando eu estava terminando 


\section{entrevista|}

Carolinne Mendes

o mestrado, eu falei "Meu, e agora? Vou trabalhar com o quê até que eu entre no doutorado? Não sei se eu vou conseguir bolsa novamente...". Enfim, já estava cansada, assim, daquela instabilidade e surgiu na época um concurso para a prefeitura de São Paulo e eu falei “Bom, vou prestar...Vou ver no que dá!”.

Na época, eu já tinha alguns colegas que já estavam trabalhando como professores da prefeitura e que me falavam que, apesar de realmente ser difícil, a prefeitura de São Paulo ainda tinha um salário razoável; ainda tinha um plano de carreira atrativo; e ainda era um trabalho meio período. Então, se eu queria continuar na trajetória acadêmica, fazer um doutorado no futuro, esses meus amigos me aconselhavam "a prefeitura pode ser um trampo legal, porque você vai ter um salário razoável, vai trabalhar só meio período e ainda vai conseguir fazer uma pesquisa". Resolvi prestar o concurso; entrei.

Não sei se vocês conhecem muito bem como que funciona ser professor da prefeitura de São Paulo, então, só para explicar um pouco: a prefeitura só tem uma carga horária, que são 25 horas-aula, que você tem mais três horas de atividades, que o professor prepara suas atividades, corrige, etc... Teoricamente, funciona com um sistema de dois professores na sala de aula; em cada turma dois professores de História, de Matemática, de Geografia, etc... Como que fica determinado quem é o professor titular e quem é o outro? Na atribuição de aulas, pela pontuação dos professores; essa pontuação é determinada tanto pelos cursos, mestrado, doutorado, especialização, etc., quanto pelo tempo na carreira; na verdade, o tempo acaba tendo um peso maior. Então, quem está nesse início de carreira na prefeitura dificilmente consegue suas próprias turmas, vai ficar acompanhando o professor, que é a função que a gente chama de Módulo.

Eu entrei na prefeitura para ser Módulo, em uma escola que ficava próxima à COHAB [Companhia Metropolitana de Habitação de São Paulo] Raposo Tavares. Esse 


\section{entrevista}

Caminhos de uma historiadora para transformar o mundo sistema dos dois professores na sala de aula não funciona exatamente assim, porque esse professor Módulo acompanharia o titular e o substituiria quando ele falta, só que, como não existe Módulo para todas as disciplinas, na prática, o Módulo vai substituir não só aquela disciplina, mas outras também; a preferência é que eu substituísse só quando faltasse os professores de História, mas, às vezes, acontecia de faltar um professor de matemática e não ter um Módulo de matemática na escola e eu ter que substituir. Então, assim, o que mais me causou um impacto negativo, no começo, quando comecei a dar aula, foi assumir essa função de Módulo, porque eu não sabia quando ia dar aula, em qual turma... Às vezes eu entrava em uma turma hoje e mais três vezes nessa semana; outra turma eu entrava hoje e só ia retornar daqui a três ou quatro semanas... Era tudo muito imprevisível.

E, como esse professor de Módulo não consegue dar continuidade a um conteúdo, na prática os professores de Módulo fazem projetos para trabalhar com as turmas. Na época, eu já comecei a fazer o projeto de História dos afrodescendentes no Brasil, então procurava trabalhar especificamente com esse tema, trazendo, principalmente, textos pros alunos. Geralmente, eu pegava textos de jornais mesmo, de internet, que estavam em voga e trabalhava a leitura e interpretação desses textos, para procurar já fechar naquela aula, porque eu não sabia quando ia voltar. Dependendo do tempo, por exemplo, se eu tivesse uma aula dobradinha, fazia a leitura e já fazia alguma atividade com a turma, e não tinha exatamente uma continuidade; quer dizer, procurava pensar essas aulas de uma forma um pouco independente.

Eu sempre vi muita dificuldade em ser Módulo, por não ter planejamento e, também, porque o desrespeito dos alunos era ainda maior. Então, eu já achava os alunos pouco interessados com os professores que iam avaliar eles, que iam dar nota etc... O professor de Módulo, que é visto como alguém que só está substituindo, 


\section{entrevista}

Carolinne Mendes

tapando um buraco, que não vai avaliar o aluno, que não vai dar nota, ele é menos respeitado; essas foram, assim, as principais dificuldades no meu início como professora.

Por outro lado, teve uma experiência muito positiva nessa escola que eu trabalhei: tinha uma professora de História que desenvolvia um projeto que era de fazer um centro pró memória na escola, se chamava “Centro pró Memória COHAB Raposo Tavares"; esse projeto acontecia no contraturno, a prefeitura tem esse programa que hoje chama "Mais Educação", na época se chamava "Projeto Ampliar", que os professores recebem por essas aulas dadas no contraturno, os alunos que estão interessados se inscrevem, não é obrigatório; é bastante interessante. Quase todas escolas da prefeitura, pelo menos todas que eu trabalhei, sempre tinha, por exemplo, o projeto de xadrez, projeto de rádio... Então, nesse projeto os alunos que se inscreviam, junto com a professora, saiam pela comunidade, nesse horário do contraturno, entrevistando os moradores. A COHAB Raposo Tavares era um bairro bastante novo, dos anos 1980; eram moradores que moravam em uma comunidade que tinham desabado e durante a gestão da [Luiza] Erundina na prefeitura de São Paulo, ela fez essa COHAB e essas pessoas foram levadas para lá. Então, muitos moradores tinham participado do início mesmo, da criação do bairro; de ter sido levado para lá sem que tivesse uma infraestrutura; ter que lutar pelos primeiros hospitais, escolas naquela região. Então, a gente saía pela comunidade, entrevistava os moradores, pedia se tinham fotografias, se tinham recortes de jornal, alguma coisa assim, gravava essas entrevistas e, às vezes, pegava emprestado e copiava esse material, também, para fazer análise na escola.

Essa professora me convidou para esse projeto, convidou eu e um outro professor que também estava chegando na escola nesse momento e foi o que me trouxe uma experiência mais motivadora, porque eu vi o que era estar trabalhando 


\section{entrevista}

Caminhos de uma historiadora para transformar o mundo com os alunos que estavam realmente interessados; o que era estar trabalhando com uma quantidade menor de alunos, também. Calhou, também, que naquele ano a gente inscreveu o projeto para participar de uma premiação na Câmara de Vereadores de São Paulo, que chama "Prêmio Paulo Freire"; a gente ganhou esse prêmio. A partir desse momento, o projeto ficou muito reconhecido, a própria escola teve um outro olhar para o projeto e a comunidade também. Então foi muito gratificante. Por um lado, esse primeiro ano teve toda uma dificuldade, de entender essa função de Módulo; mas, por outro lado, foi o projeto que me fez continuar mesmo na profissão.

Revista Epígrafe: Você poderia falar um pouco sobre o trabalho com a EJA [Educação de Jovens e Adultos], que é absolutamente diferente do trabalho com adolescentes, em ensino fundamental e ensino médio. Você já passou por essas outras etapas, como é agora estar trabalhando com a EJA agora?

Carolinne Mendes: Então, eu estou trabalhando com a EJA desde 2018. Em outros momentos eu tinha tido algumas turmas, mas nesses dois últimos anos, eu estou trabalhando mais diretamente. E eu gosto bastante de trabalhar com a EJA, as questões são bem diferentes. Os desafios que eu vejo com os adolescentes são: procurar trazer o interesse deles, procurar chamar a atenção para o conteúdo, ou mesmo para a importância do estudar, mostrar qual pode ser o significado da aprendizagem na vida deles... Todos esses desafios que são dos adolescentes, na EJA, é completamente diferente. O desafio é mais superar as dificuldades de aprendizagem de alguém que passou muito tempo fora da escola, de alguém que não está completamente alfabetizado... E de alguém que, às vezes, em relação a alguns temas, por exemplo as questões de gênero mesmo, vai ter mais resistência, como 


\section{entrevista|}

Carolinne Mendes

ocorre com as pessoas mais velhas. Quando eu vou tratar, por exemplo, sei lá, do trabalho doméstico, de como esse trabalho deveria ser compartilhado, e não ser realizado só por mulheres. Se eu estou tratando disso com os adolescentes, já vai ter uma abertura maior para discutir o assunto, e com as pessoas mais velhas, vai ter uma resistência. Mas eu gosto muito justamente porque essas pessoas já estão mais interessadas, elas já vão para a escola muito conscientes do que elas estão fazendo ali, de qual é a importância da escola... Conscientes de que elas perderam a oportunidade em um momento, lá atrás, da vida e de que agora, para elas poderem recuperar isso, é algo que é muito importante e que elas vão querer se dedicar muito. Ainda que a EJA, nesses últimos tempos, esteja se transformando, esteja ficando cada vez mais jovem. Então é muito comum, cada vez mais comum, que o adolescente que reprovou $9^{\circ}$ ano duas, três vezes, ou $8^{\circ}$ ano, ele passou dos 15 anos, já é mandado para a EJA. E aí, com isso, a EJA está tendo cada vez mais adolescentes. A gente tem que enfrentar um outro problema, que é um deslocamento. Esses adolescentes, eles vão se sentir excluídos em uma sala com pessoas mais velhas, às vezes vão se sentir envergonhados mesmo, não vão querer participar tanto... E a gente tem que enfrentar essa dificuldade de ter, em uma mesma sala de aula, pessoas com histórias de vida e com interesses tão diferentes. Mas, ainda assim, gosto bastante. E agora, nesse momento de pandemia, a EJA é a mais prejudicada. São pessoas que geralmente são mais pobres, tiveram que trabalhar desde cedo e por isso não conseguiram fazer os seus estudos na idade esperada. São pessoas que estão inseridas no mercado de trabalho, nas funções consideradas mais subalternizadas, e que estão trabalhando presencialmente. Acredito que todos os alunos que estão entrando na plataforma, que estão em contato com os professores, dizem que continuam trabalhando normalmente, que não tiveram nenhum tipo de quarentena ou ficaram desempregados, então enfrentaram muitas dificuldades mesmo; estão 


\section{entrevista}

Caminhos de uma historiadora para transformar o mundo

enfrentando. E as dificuldades de acesso também: eu tenho duzentos alunos na EJA; desses duzentos, eu acredito que uns trinta já tenham realizado algum acesso à plataforma. Mas, assim, o acesso regular tem acontecido por praticamente quatro alunos desses duzentos. Então é muito, muito pequeno. As pessoas muitas vezes não têm o equipamento, não têm a internet... Os que acessam, são pelo celular. E muitas vezes, quando são as pessoas mais velhas, dependem de outra pessoa. São muitas dificuldades mesmo. Acho que é o grupo que está sendo mais atingido pelas dificuldades na educação no ensino remoto.

Revista Epígrafe: Saindo um pouco desse campo do ensino, que é realizado na sala de aula, gostaríamos de saber: como você entrou na área de escrita de livros didáticos?

Carolinne Mendes: Então, eu comecei a entrar nessa área no final do ano passado. O meu orientador, Maurício, perguntou se eu queria participar como freelancer fazendo material didático para uma editora para a qual ele estava trabalhando, que é a AJS, e eu topei, embora fosse um momento em que eu já estivesse no processo de escrita final da tese. Quando ele me ofereceu o trabalho, eu achei que fosse algo simples e, no decorrer do trabalho, eu fui vendo que era um pouco mais complexo, que me demandava um pouco mais de tempo e até me arrependi um pouco de ter aceitado naquele momento. Por um lado, foi bom eu ter aceitado porque eu acho que era justamente o momento em que as editoras estavam precisando de muita gente para dar conta desse edital, que é o novo PNLD [Programa Nacional do Livro Didático], e acho que foi importante ter feito naquele momento por ter conseguido contato para continuar realizando esses trabalhos nesse ano. 


\section{entrevista}

Carolinne Mendes

Revista Epígrafe: Você chegou a falar que você quase se arrependeu. Como é o dia a dia no trabalho de escrita de livro didático? Mudou alguma coisa com o novo contexto da pandemia?

Carolinne Mendes: Bom, eu só tenho essa experiência como freela. Eu não sei se essa experiência é a mesma para os autores, imagino que não, mas para a pessoa que faz freela com livro didático, de certa forma, o trabalho acaba lembrando um pouco uma linha de produção fordista [risos]. Embora sejam textos, o que acontece é que você não tem uma noção do todo para o qual você está escrevendo. Nesse primeiro trabalho que eu fiz, [isso] impactou um pouco menos, porque era um trabalho para um livro de projetos e eu fiquei responsável por um projeto específico que era de Mídia e Cidadania. Então, eu estava escrevendo sobre um tema que não ia necessariamente se relacionar com outros projetos do livro, fazia menos falta eu saber sobre o que era o restante do livro, porque era um projeto que deveria começar e se encerrar naquele texto que eu estava escrevendo. Mas, nos outros trabalhos que eu acabei fazendo esse ano, eu comecei a sentir que, quando você faz freela, você escreve aquele texto e você não sabe o todo do livro. E, também, a editora geralmente tem, pelo menos nessa minha experiência, uma pressa no texto. Uma dificuldade é, realmente, a pressão de produzir em um tempo pequeno, até porque essas editoras contratam esses freelas quando os autores já não estão dando conta de escrever o material. Então o freela trabalha de uma maneira extremamente corrida; varia um pouco de acordo com a editora, a questão da interferência no texto também. Na primeira editora que eu trabalhei, eu escrevia o texto e eles corrigiam e me mandavam. Acho que eu tive um pouco de dificuldade de entender exatamente o que eles estavam querendo. As outras editoras, e acho que por uma questão de tempo, já nem me devolviam mais o texto, porque compensava mais para eles já 


\section{entrevista}

Caminhos de uma historiadora para transformar o mundo

mexer e finalizar. No contexto da pandemia, eu acredito que não mudou tanto assim. Na verdade, para a minha experiência, fazer esse trabalho durante a pandemia foi um pouco melhor, porque eu já tinha terminado meu doutorado. No ano passado, eu fiz junto com a escrita da tese e acabou sobrecarregando mais. Esse ano eu já tinha terminado a tese e isso me deixou um pouco mais tranquila. E também estou dando aula na prefeitura, mas está um pouco mais tranquilo o trabalho. Pela própria dificuldade dos alunos com acesso, tem menos alunos acessando e nosso trabalho diminuiu um pouco. Mas, enfim, é a dificuldade de se somar com tantas outras coisas do dia a dia que foram transferidas para o computador. Então, eu acho que eu me sinto sobrecarregada, no contexto da pandemia, pelo fato de tantas outras atividades serem transferidas para o virtual, e ficar o dia inteiro na frente do computador acaba cansando. Mas, em relação ao trabalho com livros didáticos, ele já seria feito no computador mesmo, por si só não mudou muito.

Revista Epígrafe: Você fez a comparação de que é quase um modo de produção fordista, essa escrita do livro didático. E tem uma questão, também, desse trabalho que você faz, que é que você não tem autoria; não vai o seu nome, no fim das contas; seu nome vira uma nota de rodapé nesse todo. Como você vê esse formato de trabalho, que é quase fordista mesmo, no qual até sua autoria sobre ele, sua propriedade intelectual, é tirada nessa produção?

Carolinne Mendes: Isso é uma coisa bastante desanimadora mesmo, você escrever um texto e saber que você não vai ter autoria por aquilo. Mas, assim, eu aceitei o trabalho sabendo disso e consciente, de certa forma, de que é muito um trabalho pensando na questão da grana mesmo, da remuneração imediata... Pelo menos com as editoras com as quais eu tive contato, os autores recebem os direitos autorais 


\section{entrevista}

Carolinne Mendes

dependendo da venda do livro. Então, assim, se o livro for distribuído para a rede municipal, por exemplo, o autor vai ganhar uma bolada... Não consigo mensurar o quanto é desproporcional em comparação com o que o freela ganhou. Mas, por outro lado, se o livro não for adotado por nenhuma escola, imagino eu, o autor não vai ganhar tanto e, no caso, o freela já tem aquela renda garantida pelo que ele já fez. Então, quando eu aceitei, eu meio que já aceitei seduzida, digamos assim, por essa promessa do dinheiro certo. Na realidade, a remuneração não é tão rápida, o freela que não é MEl acaba passando por uma burocracia maior para ser pago, pode demorar meses para receber. É o meu caso, como funcionária pública não posso ser $\mathrm{MEl}$, e como pessoa física demoro para receber das editoras e ainda tenho muito desconto nesse pagamento. Comparando com o que ocorre com o autor, como ele depende da venda, imagino que ele demora ainda mais do que o freela para ser remunerado. Mas, claro que se eu já tivesse a oportunidade como autora, eu mesma ia preferir. Inclusive, eu terminei esses trabalhos de freela agora e as editoras estão começando a trabalhar no objeto três desse edital, e o objeto três são livros de formação continuada para professores e gestores das escolas; o professor Maurício, meu orientador, que me colocou nesse meio, sugeriu que eu apresentasse para as editoras um projeto de um livro autoral sobre a questão de Cinema e História. Eu escrevi para essas editoras e não tive nenhuma resposta, então é uma coisa que me deixou bastante chateada. Mesmo sendo alguém com experiência em sala de aula, com titulação acadêmica, alguém cujos textos foram elogiados... Para essas editoras, como freela eu sirvo, como autora não.

Revista Epígrafe: A gente estava falando sobre o trabalho de pesquisa ser super autoral e a escrita de livros didáticos ser uma coisa bem diferente desse contexto. Como você enxerga a relação entre essas duas coisas? 


\section{entrevista}

Caminhos de uma historiadora para transformar o mundo

Carolinne Mendes: Na real, eu acho tão diferente, embora os dois trabalhos sejam produzir letrinhas que façam algum sentido, é tão diferente... Quando eu estou escrevendo um texto, seja uma tese, uma dissertação ou um artigo, eu acho que realmente o meu apego pelo texto é maior, no sentido de pensar que cada linha daquele texto é fruto de um trabalho que vem muito antes de se iniciar a escrita e de reflexões que dizem muito para mim, são muito importantes de uma forma pessoal mesmo. Em relação ao texto para o livro didático, eu acho que, justamente por ser dessa forma, eu já encarei como uma produção a ser vendida, sabe? Então, eu já tinha muito especificados os tópicos e subtópicos a serem abordados e eu já via muito menos possibilidade de criação, de colocar questões pessoais ali, pessoais no sentido de questões que eu considero importantes para tratar naquele assunto. Só dando um exemplo para ficar mais claro: eu escrevi um texto que era para um capítulo sobre violência. Era um capítulo bastante interdisciplinar, que o tema geral era violência, mas, dentro desse capítulo, a editora já me pedia como subtítulos "violência na Idade Média", trazendo a questão da Inquisição, e "violência durante a Segunda Guerra Mundial", trazendo o Holocausto. Então, era um capítulo que não iria percorrer a violência na história toda, mas ia pegar alguns recortes; nisso, fiquei pensando que eu acho que realmente não seriam os recortes que eu faria, sabe? Eu fiquei pensando como é que eu traria a questão mais para o Brasil, e eu não tinha poder de mudar aquilo, porque já estava bem determinado pela editora. Nesse ponto, eu vejo como é bem diferente do trabalho acadêmico. Mas, em alguns momentos, eu acho que ainda dá para tentar se colocar, tentar colocar, de certa forma, a minha marca, as questões que eu acho importantes. Então, por exemplo, naquele projeto que eu fiz ano passado sobre Mídia e Cidadania, eu procurei pensar muito na questão da escolha de imagens. A editora pedia imagens para cada subtítulo 


\section{entrevista}

Carolinne Mendes

do capítulo, e o capítulo era, basicamente, propor um projeto de jornalismo comunitário na escola. Então, você tinha que explicar passo a passo a pesquisa jornalística, a produção de texto, entrevista com as pessoas... e ilustrar cada parte com essas imagens. E, aí, uma coisa que eu procurei era trazer imagens de pessoas negras, e eu comecei a ver essa dificuldade, porque eu colocava no Google "repórter", "redator" e não apareciam, por exemplo, mulheres negras. Então eu tinha que colocar "repórter mulher negra". E não sei exatamente como ficou a versão final esse material, dá realmente aquele aperto no coração, porque eu não sei se as imagens que eu mandei ficaram justamente assim. Mas pensar que eu possa ter influenciado isso de alguma forma é um ponto positivo, é o espaço que a gente tem de colocar uma marca, mesmo que aquele trabalho seja sob encomenda e já tenha pontos muito específicos para serem preenchidos.

Revista Epígrafe: Queríamos saber se tem alguma habilidade específica do historiador que é exigida durante esse processo de escrita dos livros didáticos.

Carolinne Mendes: Bom, eu acho que é mais em relação à escrita mesmo... Mesmo sem fazer uma pesquisa com documentação, no livro didático você narra a história. O que é possível também, é você propor atividades com documentos históricos, então isso é uma habilidade do historiador que fica mais presente nesses livros didáticos, dependendo do formato que a editora está pedindo. Mas eu estou pensando, por exemplo, nos manuais do professor, que é uma coisa que eu acho que as editoras contratam bastante freelas também. Nesses manuais é possível sugerir atividades extras que não estão no livro do estudante; tem um espaço, por exemplo, para você trabalhar um documento histórico... E nesses manuais, você dá instruções para o professor. Acho que ali você pode pensar um pouco como trazer esse ofício do 


\section{entrevista}

Caminhos de uma historiadora para transformar o mundo historiador para a sala de aula também, na forma que você vai orientar o professor a trabalhar com os alunos, a propor novas atividades... Mas, no livro do estudante, pelo menos nos trabalhos que eu fiz, já eram muito especificados os tópicos, fica mais difícil. Até em relação às imagens nas editoras com as quais eu trabalhei, por exemplo, elas estavam previstas em livros de estudante só como ilustrações, não tinha muito espaço para trabalhar com a imagem como um documento histórico, por exemplo, apenas no livro do professor mesmo.

Revista Epígrafe: Voltando um pouco na sua resposta anterior, da escolha dos temas, queríamos que você falasse um pouco mais sobre isso, e aí pensando tanto a escola, quanto esse espaço do livro didático. E pensando, também, que você não tem essa liberdade no livro... Agora, nesse trabalho específico que você está fazendo, você não tem essa liberdade de escolha.

Carolinne Mendes: Eu acho que uma coisa que eu procuro fazer, enquanto professora, é pensar como fazer a ligação do presente com os temas históricos. E eu percebo pelo material que me foi requisitado pelas editoras que é um caminho que os livros didáticos também estão tomando, de procurar fazer essa relação dos livros de História com o momento presente. Por exemplo, duas editoras me chamaram esse ano para escrever capítulos que, de alguma forma, envolviam relações raciais, fosse sobre racismo ou sobre cidadania de pessoas indígenas e afrodescendentes... E eu realmente não sei se é porque é um tema que está muito em voga no momento presente, e aí as editoras se voltaram para isso mais do que acontecia, ou se os próprios autores desses capítulos começaram a pensar que seria importante escolher autores negros para escrever sobre eles, e essas editoras me contrataram já pensando nisso de eu ser uma pessoa negra para escrever sobre esses temas... Então 


\section{entrevista|}

Carolinne Mendes

não tenho muita clareza sobre isso, mas acho que tem essas possibilidades. E essa conexão entre presente e os assuntos históricos é uma coisa que eu procuro trazer nas minhas aulas. E aí eu faço relação com as minhas pesquisas também. Então, por exemplo, questões raciais, questões de gênero, costumam surgir muito nas minhas aulas. Dando aula como Módulo, como eu não tenho que cumprir o currículo de História, eu tenho uma autonomia total em relação à escolha desses temas. Mas mesmo quando eu dava aula no Estado, por exemplo, que eu deveria seguir o currículo, eu procurava também trazer algumas coisas. E até pensando nos livros didáticos que eu usava nessa época... Eu dei aula no Estado de 2014 até 2017, então acho que os livros didáticos que eu usava não traziam tanto, por exemplo, a questão de gênero, diferente dos livros com os quais eu trabalhei agora... Mas mesmo que os livros não trouxessem, eu procurava introduzir esses temas. Ainda que, às vezes, eu tivesse uma dificuldade em mostrar que, por exemplo, as mulheres, elas estão presentes na História, mas, às vezes, pelo próprio livro não trazer, a minha dificuldade era mostrar como não era só uma coisa à parte. Por exemplo, estudamos Império Romano, e aí tem lá a sequência do livro didático, e depois eu vou trazer uma aula sobre mulheres no Império Romano, no caso com um material que eu, enquanto professora, pesquisei e trouxe para os meus alunos. Então a dificuldade, nesse caso, era articular esse material para mostrar que aquilo não é uma história à parte, é uma história que deveria estar inserida ali naquele livro didático e que não foi inserida por uma escolha dos historiadores, dos autores e por aí vai. Mas eu acho que eu acabei assumindo, mesmo, uma postura bastante engajada como professora, de procurar trazer os temas que eram também os temas das minhas pesquisas acadêmicas. E nos livros didáticos também, ainda que na medida do possível, na escolha de uma imagem ou em algum recorte. Estou lembrando, aqui, por exemplo, no texto que eu escrevi para o livro didático sobre violência, aí tinha lá o subtítulo "tipos de violência". 


\section{entrevista}

Caminhos de uma historiadora para transformar o mundo

Eu lembro que tinha genocídio. Aí, por exemplo, para falar do genocídio, eu procurei fazer um recorte específico de raça no Brasil. Então, é aquilo: eu não sei como é que esse texto vai chegar no produto final lá do livro didático, mas na medida do possível, onde eu pude fazer algum recorte temático, eu procuro inserir esses temas que são os que eu pesquiso e que considero importantes.

Revista Epígrafe: Ainda falando sobre esse espaço do livro didático, teve algum conhecimento que é necessário para trabalhar nessa área e que você precisou buscar fora da universidade, fora do curso de História?

Carolinne Mendes: Eu acho que eu precisei dar uma olhada em alguns livros sobre práticas educativas, em alguns artigos sobre metodologias ativas, que é uma coisa que as editoras estão pedindo bastante atualmente, e que eram coisas sobre as quais eu não tinha me debruçado tanto na licenciatura. E aí eu realmente fico pensando se é porque eu fiz essa licenciatura na qual eu não estava tão dedicada, ou se é porque eu concluí a minha licenciatura em 2009, então acho que algumas coisas vão mudando. Mas enfim, coisas que eu não tinha estudado tanto, como essa questão das metodologias ativas, eu tive que buscar um pouco, e aí, principalmente na pandemia, com a dificuldade de não ter biblioteca, buscar na internet, mesmo, artigos ou livros em $p d f$, o que eu conseguia, para trazer isso. Principalmente para escrever a parte de manual do professor do livro didático. Porque a parte do livro do aluno, claro que tem um formato diferente, uma linguagem diferente de um texto historiográfico, mas ainda é um texto que gira em torno dos temas históricos mesmo. Mas na parte do manual do professor, você vai ter um texto onde interessa mais a questão da didática, a questão de como o professor vai trabalhar aquele conteúdo, que tipos de atividades ele pode passar. Então, quando eu comecei a fazer esse material, as 


\section{entrevista}

Carolinne Mendes

editoras cobravam muito que as atividades fossem explicadas minuciosamente para os professores. Embora eu atuasse como professora, ou talvez até por eu atuar como professora, eu achava que não era necessário explicar, por exemplo, para o professor como fazer uma roda de conversa. Eu escrevia lá: “Ah, para tratar desse tema, faça uma roda de conversa com os seus alunos.". E aí a editora me retornava: "Não, você precisa explicar como é que vai ser feita essa roda de conversa, você precisa trazer um parágrafo para falar para o professor a importância de ele escutar os alunos...". Quando eu comecei a escrever isso, eu senti uma dificuldade em encontrar as palavras, mesmo, para detalhar tanto isso, eu precisei ir buscar alguns materiais.

Revista Epígrafe: Qual é o espaço do historiador no mercado de trabalho fazendo essa espécie de freela, que não é necessariamente no mundo acadêmico e também não é na escola? Como é que você vê o historiador ocupando esses outros espaços, que não são espaços que a gente vê como óbvios durante a graduação; como você se encontra, enquanto historiadora, nesses lugares?

Carolinne Mendes: Bom, eu acho que, infelizmente, como praticamente todos os mercados de trabalho, ainda é muito precária a inserção do historiador nesses espaços. Ainda depende muito, por exemplo, dos contatos. Provavelmente, se eu mandasse currículo para essas editoras oferecendo meu trabalho, provavelmente não iriam me contratar, não iriam me chamar. Então foi essencial ter o contato do meu orientador. Depende muito, também, de você ter uma disponibilidade para atender isso em um curto espaço de tempo. Não é um trabalho que você consiga se planejar para fazer, vai muito de você atender às demandas da editora no momento no qual eles estão precisando. E você não sabe se vai ter continuidade também, então tem toda essa questão da instabilidade. Pelo que eu tenho visto, os editais de livro 


\section{entrevista}

Caminhos de uma historiadora para transformar o mundo

didático acontecem todo ano intercalando, um ano [Ensino] Fundamental I, um ano [Ensino] Fundamental II e um ano Ensino Médio. Não tenho tanta experiência para dizer, mas eu imagino, por exemplo, que no edital de Fundamental I que vai ser, no caso, no ano que vem, não seja necessário contratar tantos historiadores. Imagino que provavelmente vão contratar mais pedagogos. Então o historiador fica muito instável nessa função, eu acredito. E também não é uma coisa que você faz o ano inteiro. A editora tem um período específico onde ela está precisando desses textos, depois acaba e você também fica sem grana se você depende disso. Então eu vejo muito como um trabalho que, infelizmente, acaba servindo mais para se combinar com uma trajetória acadêmica, porque por não ter vínculo empregatício, por ser um freela, você pode fazer ao mesmo tempo que você recebe uma bolsa, por exemplo. E aí você pode ter uma certa "segurança", entre aspas, com essa bolsa, porque a bolsa também não é uma coisa que te deixa totalmente estável, mas, digamos, você ainda tem uma outra fonte de renda. Então você vai fazer, um mês, um trabalho para a editora, e aí depois, no mês que vem, você não vai ter, mas você ainda vai ter a sua bolsa, por exemplo. Eu acho que com a função do professor também é uma boa combinação, porque, por exemplo, ainda é menos desgastante para mim dar aulas meio período e fazer no restante do dia um trabalho para livro didático. Ainda é menos desgastante do que dar aulas em dois períodos. Então eu acho que é um trabalho que, combinado com outros, pode ser interessante, mas que infelizmente reflete essa precariedade do historiador tentar se inserir de uma forma estável, de uma forma regulamentada, de uma forma em que ele tenha os seus direitos e a sua autoria, a autoria dos seus textos, reconhecida.

Revista Epígrafe: Como é que você, enquanto uma mulher negra, se vê nesses espaços de trabalho? Seja como professora ou seja como pesquisadora, ou fazendo 


\section{entrevista}

Carolinne Mendes

esses outros trabalhos... Como é que você se vê como mulher negra, como uma profissional, como uma historiadora? Como se coloca essa questão, o que te traz essa questão?

Carolinne Mendes: Bom, eu acho que, primeiro, o que me traz é uma questão de pensar o meu papel nesses lugares, nesses trabalhos. E de pensar como, ainda que seja em uma escala muito pequena, eu posso atuar para modificar uma realidade de opressões que eu acho que eu, enquanto mulher negra, sofro. Então, por exemplo, seja trazendo a discussão sobre o sistema, sobre racismo, sobre machismo na escola, mesmo não podendo escolher tanto os temas nos livros didáticos, mas, na medida do possível, tentando inserir esses temas, ainda que sejam nas entrelinhas. Ou mesmo quando o material didático já é sobre racismo, eu acho que é bastante interessante, para mim, poder me colocar diante desse assunto. Então, por exemplo, uma editora que eu fiz um livro do professor sobre racismo. Eu trouxe muito combinada a questão do racismo com o tema de gênero, e a autora gostou bastante do capítulo que eu tinha feito e pediu para eu revisar um outro capítulo que era sobre violência contra a mulher, mas que ela achou que a pessoa que fez o livro do professor sobre aquele capítulo não tinha trabalhado tão bem o tema. É bom saber que eu posso me inserir nesse campo, escrever coisas que vão ser trabalhadas na sala de aula. Me traz a sensação de que eu tenho alguma atuação aí, sobre o mundo, mesmo que ainda muito limitada. E fico refletindo bastante sobre o quanto eu ser mulher negra não reflete diretamente nessa precarização do trabalho. Então, por exemplo, o fato de eu estar como freela, e não como autora do livro didático; o fato de, na prefeitura, eu ainda estar como professora de Módulo. Uma coisa, por exemplo, que aconteceu agora, durante a pandemia. Na prefeitura, acontece assim: os professores que não são Módulo, mas têm as salas deles mesmo, eles podem fazer uma coisa que a gente 


\section{entrevista}

Caminhos de uma historiadora para transformar o mundo chama de JEIF [Jornada Especial Integral de Formação], que é uma Jornada de Formação. Então, além das aulas, eles têm um momento que é como se fosse uma reunião pedagógica, todas as semanas, nas quais eles discutem textos pedagógicos ou questões sobre a escola. E aí, por fazerem essa Jornada de Formação, eles recebem um salário bem maior do que os professores de Módulo. E aí, na pandemia, tem uma reunião que está acontecendo online, para essa Jornada de Formação. Só que, na minha escola, os professores que trabalham na EJA, e, no caso, eu trabalho na EJA, eles trocaram essa Jornada de Formação por discutir questões específicas da EJA. E aí o coordenador chamou os professores que são Módulo para também fazer parte dessa discussão; a gente também trabalha com a EJA, então a gente tem que estar lá presente. E aconteceu que as professoras que são Módulo, ou seja, que não estão recebendo por essa JEIF, mas que estão participando, são justamente eu e uma outra professora negra. Então, estruturalmente, claro que não é um sistema direto, “Você é negra, então você não tem direito a JEIF", não. Mas, estruturalmente, eu acho que os espaços que a gente ocupa, como professora, você não conseguir ter suas próprias turmas; como alguém que está fazendo trabalhos para livro didático, você não conseguir se colocar como autora... Estruturalmente, isso com certeza tem a ver com essa posição social de ser mulher e de ser negra. Essa reflexão fica muito evidente para mim.

Revista Epígrafe: Que dica você daria para um estudante que quer trabalhar em algumas dessas áreas, seja como professor, seja como escritor de livros didáticos... Quais são as dicas que você daria, como alguém que está nessas áreas?

Carolinne Mendes: Eu acho que a primeira dica que eu daria é que, enfim, cada um vive uma realidade, nem sempre é possível... Mas eu acho que vale a pena, durante a 


\section{entrevista|}

Carolinne Mendes

graduação, tentar experimentar as diferentes áreas que são possíveis de trabalhar. Eu fui mudando de estágio em estágio, como eu falei para vocês, e é uma coisa da qual eu não me arrependo, de ter conhecido um pouco do trabalho em diferentes lugares para entender mesmo com o que eu me identificava mais e quais as vantagens e desvantagens de cada tipo de trabalho. Você só vai perceber isso na prática. É na prática que você, trabalhando, vai perceber se encaixa para você ou não. Outra dica que eu daria é que, embora eu ache que a experiência de estágio da licenciatura é muito desanimadora para grande parte dos alunos de graduação, a experiência de dar aula também é algo que vale a pena ser tentado. E é completamente diferente você entrar em uma sala de aula enquanto estagiário, que está só observando, e você ser, de fato, a pessoa que vai ministrar aquela aula. Então eu acho que só vivenciando que você consegue saber o que é isso também. Eu mesma tinha o maior preconceito no sentido de falar: "Isso é a minha última opção". E hoje eu falo: "Dar aula foi a melhor coisa que eu fiz". Outra questão, embora pareça uma coisa muito pragmática, às vezes até mal vista, que é a questão de buscar contatos [risos]. Infelizmente, às vezes é a única forma de você conseguir determinados trabalhos. Então eu acho que vale a pena conversar com os professores, no sentido de que eles acabam tendo contato com o que você produz, com os textos que você produz, seja para um trabalho, para uma prova... São pessoas que podem ser um contato importante para conseguir algum tipo de trabalho. Comigo mesmo foi assim, no caso da minha relação com o meu orientador. Eu acho que também vale a pena ficar de olho nos concursos públicos onde o historiador pode participar, seja como professor ou seja para atuar em museus ou outras instituições. Por mais que, às vezes, aquela atividade não te pareça tão interessante, eu acho que vale pensar nessa oportunidade, pensar que é um trabalho que de repente você consegue conciliar com outras coisas, e que vai te trazer alguma vantagem nesse sentido de estabilidade mesmo. Acho que é isso. 